\title{
Design, Synthesis, and In Vitro Evaluation of Novel Histone H3 Peptide-Based LSD1 Inactivators Incorporating $\alpha, \alpha$-Disubstituted Amino Acids with $\gamma$-Turn-Inducing Structures
}

\author{
Yosuke Ota ${ }^{1, *}$, Taeko Kakizawa ${ }^{2}$, Yukihiro Itoh ${ }^{1}$ (iD) and Takayoshi Suzuki 1,3,* (iD) \\ 1 Department of Chemistry, Graduate School of Medical Science, Kyoto Prefectural University of Medicine, \\ 1-5 Shimogamohangi-Cho, Sakyo-Ku, Kyoto 606-0823, Japan; itohy@koto.kpu-m.ac.jp \\ 2 Department of Chemistry and Biochemistry, School of Advanced Science and Engineering, \\ Waseda University, Shinjuku, Tokyo 169-8555, Japan; kg100683@kanto-gakuin.ac.jp \\ 3 Core Research for Evolutional Science and Technology (CREST), \\ Japan Science and Technology Agency (JST), 4-1-8 Honcho, Kawaguchi, Saitama 332-0012, Japan \\ * Correspondence: y-ota@koto.kpu-m.ac.jp (Y.O.); suzukit@koto.kpu-m.ac.jp (T.S.); \\ Tel.: +81-75-703-4937 (T.S.)
}

Academic Editor: Takaomi Sanda

Received: 2 May 2018; Accepted: 4 May 2018; Published: 6 May 2018

\begin{abstract}
Lysine-specific demethylase 1 (LSD1) mainly removes methyl groups of mono- or di-methylated lysine residues at the fourth position of histone $\mathrm{H} 3$ to epigenetically regulate the expression of genes associated with several diseases, such as cancer. Therefore, LSD1 inactivators are expected to be used as therapeutic agents. In this study, to identify novel peptide-based LSD1 inactivators, we focused on the X-ray structure of LSD1 complexed with a H3 peptide-based suicide substrate. It has been proposed that a methylated histone substrate forms three consecutive $\gamma$-turn structures in the active pocket of LSD1. Based on this, we designed and synthesized novel histone H3 peptide-based LSD1 inactivators $\mathbf{2 a - c}$ by incorporating various $\alpha, \alpha$-disubstituted amino acids with $\gamma$-turn-inducing structures. Among synthetic peptides $\mathbf{2 a - c}$, peptide $\mathbf{2 b}$ incorporating two 1-aminocyclohexanecarboxylic acids at both sides of a lysine residue bearing a trans-2-phenylcyclopropylamine (PCPA) moiety, which is a pharmacophore for LSD1 inactivation, was the most potent and selective LSD1 inactivator. These findings are useful for the further development of histone H3 peptide-based LSD1 inactivators.
\end{abstract}

Keywords: epigenetics; histone; lysine-specific demethylase 1 (LSD1); inhibitor; $\gamma$-turn structure

\section{Introduction}

The methylation of lysine residues on histones is involved in the epigenetic control of gene expression associated with not only many cellular events but also several diseases [1]. Histone methylation and demethylation reactions are catalyzed by a series of histone lysine methyltransferases (HKMTs) and histone lysine demethylases (KDMs), respectively [1]. Thus, the methylation is reversibly regulated by both HKMTs and KDMs.

Lysine-specific demethylase 1 (LSD1), which is one of the KDMs and a flavin adenine dinucleotide (FAD)-dependent oxidase, catalytically removes the methyl groups of mono- or di-methylated lysine residues at the fourth position of histone H3 (H3K4me1/me2) [2]. In prostate cancer cells, LSD1 acquires H3K9me1/me2 demethylation activity by interacting with an androgen receptor [3]. In addition, LSD1 demethylates methyl groups of mono- or di-methylated lysine residues of non-histone proteins 
(e.g., p53, DNMT, and E2F1) to regulate their activities and functions [4-6]. LSD1 forms a co-repression complex with CoREST, recruiting other transcription factors, such as HDAC1, Gfi-1b, TLX, KHMTs, and other KDMs [7-11], to epigenetically regulate the expression of the genes associated with several diseases, such as cancer, globin disorders, and viral infections [12-14]. Therefore, LSD1 is interesting as a molecular target for the therapy of diseases. To date, a number of LSD1 inactivators have been developed [15-17] and some of them are being evaluated in clinical trials for cancer [18,19].

We have reported several peptide- or small molecule-based LSD1 inactivators so far [20-29]. For instance, PCPA-Lys-4 H3-21, a peptide-based LSD1 inactivator [22] (Figure 1), drops off trans-2-phenylcyclopropylamine (PCPA), a pharmacophore for LSD1 inactivation [30,31], in the active pocket of LSD1 to inactivate LSD1 potently and selectively. Further, we identified NCD38, a potent and selective small molecule LSD1 inhibitor [22] (Figure 1) that showed sufficient bioactivity in in vivo studies [32,33]. Following these findings, we considered that it is possible to improve the LSD1 inhibitory activities of peptide- or small molecule-based LSD1 inactivators. In particular, a novel design of peptide-based LSD1 inactivators could lead to high specificity toward LSD1 and their off-target effects could be limited as compared with small molecule inhibitors. Thus, peptide-based LSD1 inactivators could exhibit high therapeutic potential toward LSD1-associated diseases [12-14].

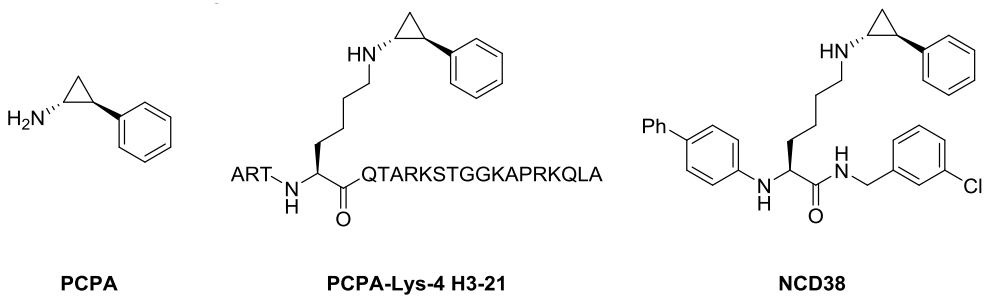

Figure 1. Structures of trans-2-phenylcyclopropylamine (PCPA) and its analogs as LSD1 inactivators.

In 2007, Cole, Yu, and co-workers reported a co-crystal structure of LSD1 with a histone H3-based suicide substrate incorporating $N$-methylpropargylamine, and revealed that the substrate reacted with FAD to form three consecutive $\gamma$-turn structures in the active pocket of LSD1 (Figure 2) [34]. The unique secondary structures could contribute to the substrate specificity toward LSD1 [34]. Based on that report, we envisioned that the LSD1 inhibitory activities of peptide-based inactivators would be improved by regulating their secondary structures. Thus, peptides that easily form three consecutive $\gamma$-turn structures should exhibit strong LSD1 inhibitory activity and high selectivity. Herein we report novel histone H3 peptide-based LSD1 inactivators incorporating $\alpha, \alpha$-disubstituted amino acids that work as $\gamma$-turn inducers.

(A)

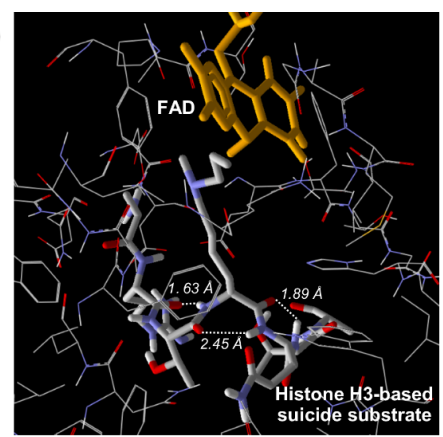

(B)

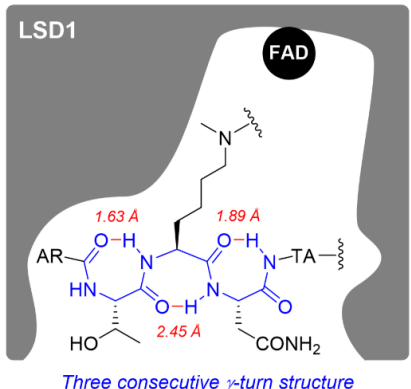

Throne $\mathrm{H}$ 3-based suicide substrate

Figure 2. Secondary structure of a histone H3-based suicide substrate in the active pocket of LSD1 (PDB: 2UXN). (A) View of the secondary structure of the histone H3-based suicide substrate in the active pocket of LSD1. Intramolecular hydrogen bonds are indicated by the white dotted line and their lengths are shown in italics. (B) Schematic diagram of the secondary structure of the histone H3-based suicide substrate in the active pocket of LSD1. Intramolecular hydrogen bonds are indicated by the red line and their lengths are shown in italics. 


\section{Results}

\subsection{Design}

Previously, it was reported that $\alpha, \alpha$-disubstituted amino acids predominantly induced the formation of $\gamma$-turn structures [35]. Thus, we hypothesized that the introduction of $\alpha, \alpha$-disubstituted amino acids into the sequence of a histone H3-based peptide would stabilize the formation of three consecutive $\gamma$-turn structures in the active pocket of LSD1. To verify the hypothesis, we selected LSD1 inactivator $\mathbf{1}$ as the model and reference peptide (Figure 3), because peptide $\mathbf{1}$ has both a concise sequence and appropriate LSD1 inhibitory activity [28]. We designed histone H3 peptide-based LSD1 inactivators $2 \mathbf{a}-\mathbf{c}$ by incorporating two of the following $\alpha, \alpha$-disubstituted amino acids: 2-aminoisobutyric acid (Aib) (2a), 1-aminocyclohexanecarboxylic acid (Acc) (2b), and 2-aminoadamantane-2-carboxylic acid (Aadc) (2c), one on each side of the lysine residue bearing a PCPA moiety (Figure 3).

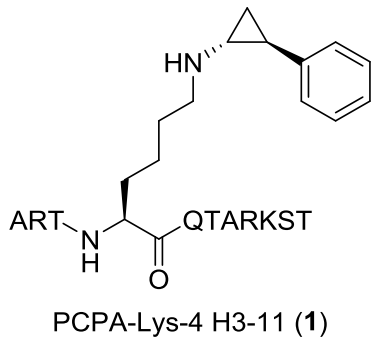

PCPA-Lys-4 H3-11 (1)

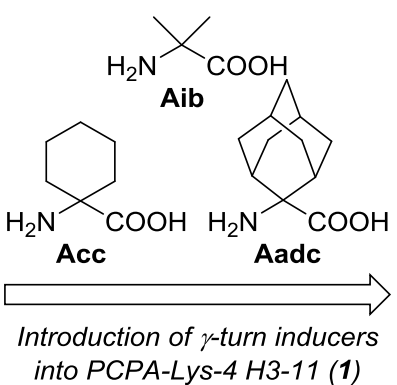

into PCPA-Lys-4 H3-11 (1)

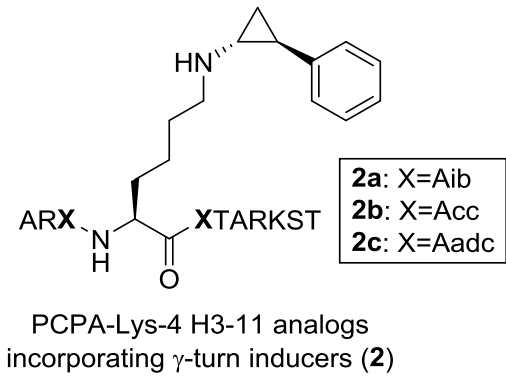

PCPA-Lys-4 H3-11 analogs

incorporating $\gamma$-turn inducers (2)

Figure 3. Structure of PCPA-Lys 4 H3-11 (1) (left). Design of novel histone H3 peptide-based LSD1 inactivators $\mathbf{2 a}-\mathbf{c}$ incorporating $\alpha, \alpha$-disubstituted amino acids that work as $\gamma$-turn inducers (right).

\subsection{Synthesis}

The synthesis of H3-11 peptide analogs 2 is shown in Scheme 1. Peptides 2 were synthesized by Fmoc-based solid-phase peptide synthesis (SPPS) according to modified previous procedures for histone H3-based peptides [22,25,28]. Initially, we prepared peptides 3 incorporating the $\alpha, \alpha$-disubstituted amino acids by Fmoc-based SPPS. Next, peptides 3 were converted into mesylates 4 with mesyl chloride ( $\mathrm{MsCl})$, and then the mesyl groups of 4 were substituted with PCPA to obtain desired precursors 5. Precursors 5 were cleaved from the resin and purified by high-performance liquid chromatography (HPLC) followed by lyophilization and identification by matrix-assisted laser desorption/ionization time-of-flight mass spectrometry (MALDI-TOF MS) to obtain the desired peptides 2 as a white powder.

\subsection{In Vitro Evaluation of LSD1 Inhibitory Activity}

We assayed for the LSD1 inhibitory activities of novel peptides 2a-c. The assay was performed with an LSD1 Fluorometric Drug Discovery Kit (Enzo Life Sciences, New York, NY, USA, BML-AK544-0001). The results are summarized in Table 1. Control peptide 1 inactivated LSD1 potently compared to PCPA. As expected, the LSD1 inhibitory activities of novel peptides 2a-c were higher than that of $\mathbf{1}$. In particular, peptide $\mathbf{2 b}$ was the most potent LSD1 inactivator among the peptides tested in this study. Next, we examined the time-dependency of LSD1 inhibition by peptides 2a-c. As shown in Supplementary Figure S1, peptide 2a-c inhibited LSD1 enzyme activities in a time-dependent manner, which indicates that peptides $2 \mathbf{a}-\mathbf{c}$ inactivate LSD1 irreversibly. We also assayed for the inhibitory activities of monoamine oxidases (MAOs), which are FAD-dependent oxidases associated with neurotransmitter metabolism [36], to investigate the selectivity toward LSD1. For this investigation, we used a MAO-Glo ${ }^{\mathrm{TM}}$ Assay System (Promega, Madison, WI, USA, V1401). 
As shown in Table 1, all peptides did not inactivate MAO-A or MAO-B at the concentration of $10 \mu \mathrm{M}$, whereas PCPA, the positive control, inactivated both MAO-A and MAO-B. Furthermore, we tested the inhibitory activities of peptides $\mathbf{2 a}-\mathbf{c}$ for KDM4C, an isoform of $\alpha$-ketoglutarate/Fe(II)-dependent KDMs [37]. As a result, peptides 2a-c hardly inhibited KDM4C activities at a concentration of $10 \mu \mathrm{M}$ (Supplementary Figure S2). Thus, the novel peptides $\mathbf{2 a}-\mathbf{c}$ were found to be irreversible LSD1-selective inactivators.
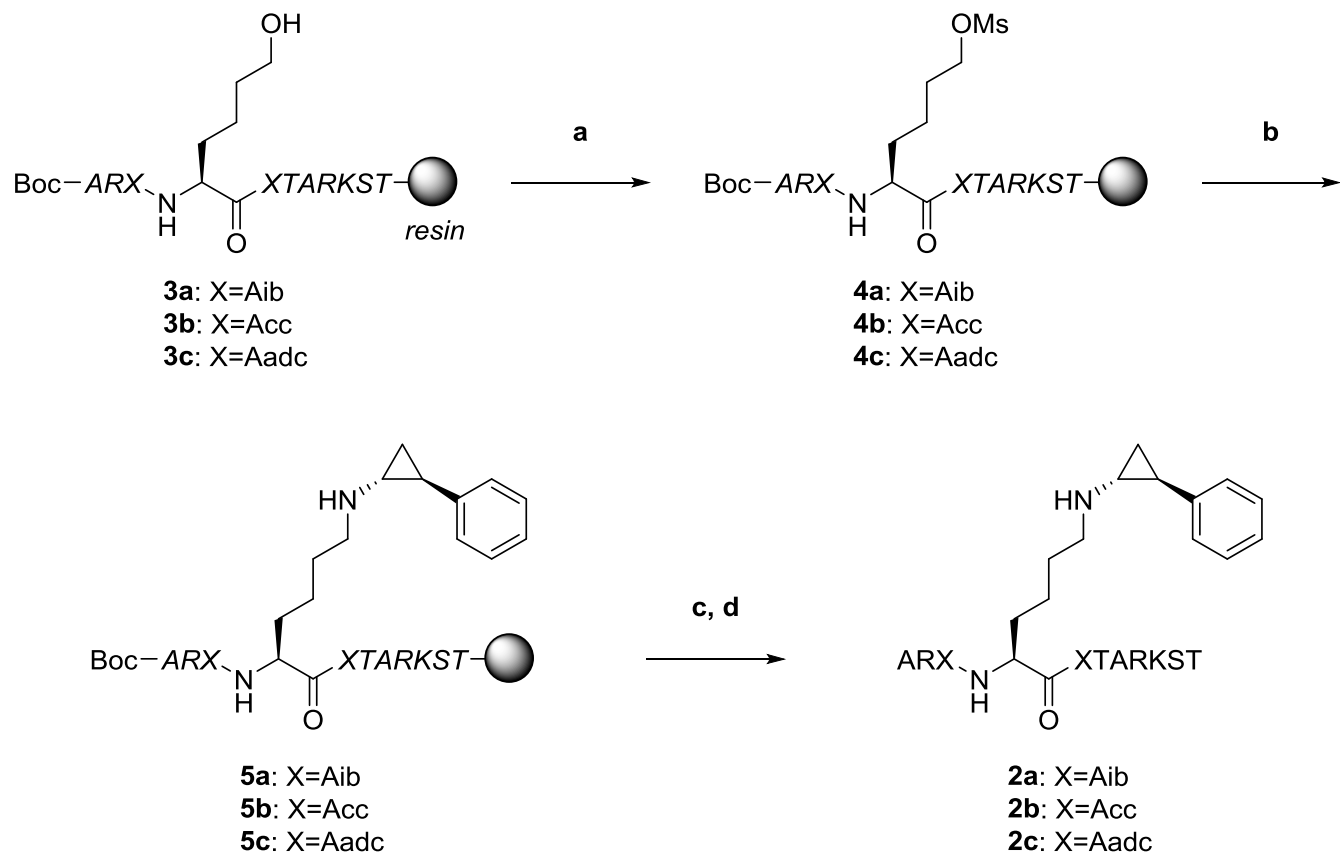

Scheme 1. Preparation of novel histone H3 peptide-based LSD1 inactivators 2a-c with $\gamma$-turn inducers by Fmoc-based SPPS (Boc-Ala-OH was used as the $\mathrm{N}$-terminal amino acid). Reagents and conditions: (a) $\mathrm{MsCl}, \mathrm{Et}_{3} \mathrm{~N}$ in THF; (b) PCPA, $\mathrm{Et}_{3} \mathrm{~N}$ in $\mathrm{H}_{2} \mathrm{O}: \mathrm{CH}_{3} \mathrm{CN}$ solution; (c) TFA, thioanisole, $\mathrm{H}_{2} \mathrm{O}$; and (d) preparative HPLC. Peptide chains shown in italics are protected.

Table 1. LSD1 and MAO inhibitory activities of peptides $\mathbf{2 a - c .}$

\begin{tabular}{ccrr}
\hline \multirow{2}{*}{ Compound } & \multicolumn{3}{c}{ IC $_{\mathbf{5 0}}(\boldsymbol{\mu M})^{\mathbf{1}}$} \\
\cline { 2 - 4 } & LSD1 & MAO-A & \multicolumn{1}{c}{ MAO-B } \\
\hline PCPA & $16.5 \pm 1.9$ & $6.00 \pm 1.38$ & $6.54 \pm 0.51$ \\
$\mathbf{1}$ & $0.126 \pm 0.002$ & $>10$ & $>10$ \\
$\mathbf{2 a}$ & $0.0891 \pm 0.0053$ & $>10$ & $>10$ \\
$\mathbf{2 b}$ & $0.0584 \pm 0.0025$ & $>10$ & $>10$ \\
$\mathbf{2 c}$ & $0.0724 \pm 0.0040$ & $>10$ & $>10$ \\
\hline \multicolumn{4}{c}{ 1 Values are means + S.D. of at least three experiments. }
\end{tabular}

\section{Discussion}

In this work, we designed and synthesized $\gamma$-turn-inducing novel peptides $\mathbf{2 a - c}$ incorporating $\alpha, \alpha$-disubstituted amino acids and evaluated them in an in vitro LSD1 inhibitory assay. We revealed that peptides $\mathbf{2 a - c}$ were potent and selective LSD1 inactivators compared to reference peptide $\mathbf{1}$. In particular, peptide $\mathbf{2 b}$ incorporating one Acc each on both sides of the lysine residue bearing the PCPA moiety showed the most potent LSD1 inhibitory activity and the highest LSD1 selectivity (>170-fold).

Based on these results and our previous findings $[22,25,28]$, we consider that peptides $2 \mathbf{a}-\mathbf{c}$ incorporating $\alpha, \alpha$-disubstituted amino acids as $\gamma$-turn inducers, particularly $\mathbf{2} \mathbf{b}$, form three consecutive $\gamma$-turn structures in the active pocket of LSD1 to be highly recognized by LSD1 and thereby strongly 
inactivating LSD1 (Figure 4). Indeed, our docking study using a short model peptide based on $\mathbf{2 b}$ suggested that it forms three consecutive $\gamma$-turn structures and binds to the active pocket of LSD1 (Supplementary Figure S3). Although we have not obtained any experimental results regarding the secondary structures of the peptides incorporating $\alpha, \alpha$-disubstituted amino acids in the active pocket of LSD1, structural investigation using various approaches, such as NMR analysis and computational chemistry, is underway.

The structures of peptides are often a source of problems, such as low membrane permeability or low tolerance to proteases, but those problems could be solved by introducing drug delivery systems [38]. Meanwhile, it was reported that more hydrophobic histone H3-based cyclic peptides penetrate the cell membrane to exert an antiproliferative effect on cancer cells by inhibiting LSD1 in the cells, but less hydrophobic non-cyclic ones do not [39,40]. Recently, it was also reported that a more hydrophobic H3-based cyclic peptide stabilized by a disulfide bridge penetrates the cell membrane and inhibits LSD1, thereby inducing histone methylation, whereas a less hydrophobic non-cyclic one does not [41]. Thus, we speculate that our peptides incorporating $\alpha, \alpha$-disubstituted amino acids might passively penetrate the cell membrane to regulate LSD1 cellular function, because the peptides have hydrophobic properties and secondary structures stabilized by $\gamma$-turn inducers. In addition, it was reported that the introduction of unnatural amino acids into the original peptide sequence could improve the tolerance to protease [39,42]. Thus, we also expect that our peptides would exhibit protease tolerance. In the future, we are going to test the cellular activities of our peptides.

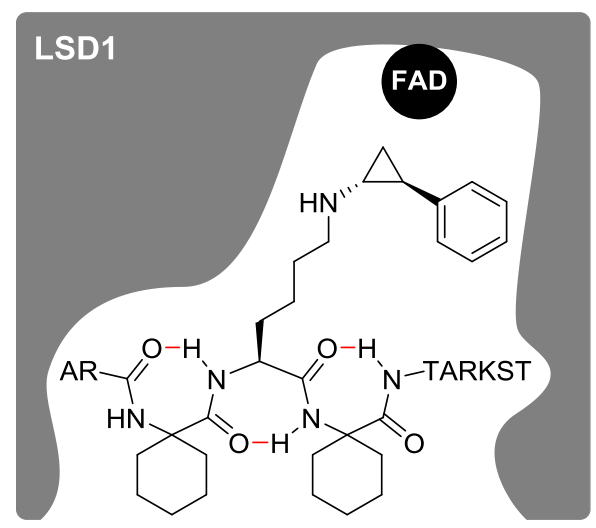

Figure 4. A proposed secondary structure of histone H3 peptide-based LSD1 inactivator $\mathbf{2} \mathbf{b}$ in the active pocket of LSD1 is shown in a schematic diagram. Intramolecular hydrogen bonds are indicated in red.

\section{Materials and Methods}

\subsection{General Methods}

All reagents were purchased and used as received. Fmoc-Aib-OH and Fmoc-Acc-OH were purchased from Watanabe Chemical Industries (Hiroshima, Japan). Fmoc-Aadc-OH was prepared from H-Aadc-OH (Ark Pharm, Arlington Heights, IL, USA) via a standard method for Fmoc introduction [43]. Obtained peptides were purified by preparative HPLC and the purity was estimated by analytical HPLC. Preparative HPLC was performed with a pump system of JASCO PU-2028 Plus (JASCO , Tokyo, Japan) and a Cosmosil 5C 18 -AR-II column $(20 \times 250 \mathrm{~mm}$, Nacalai Tesque, Kyoto, Japan) using a linear gradient of $0.1 \%$ trifluoroacetic acid (TFA) in $\mathrm{CH}_{3} \mathrm{CN}$ and $0.1 \%$ aqueous TFA at the flow rate of $5.0 \mathrm{~mL} \mathrm{~min}^{-1}$, and detection was at $220 \mathrm{~nm}$. Analytical HPLC was carried out with a pump system of JASCO PU-2028 Plus and a Cosmosil 5C 18 -AR-II column $(4.6 \times 250 \mathrm{~mm}$, Nacalai Tesque) using a linear gradient of $0.1 \%$ TFA in $\mathrm{CH}_{3} \mathrm{CN}$ and $0.1 \%$ TFA in $\mathrm{H}_{2} \mathrm{O}\left(1.0 \mathrm{~mL} \mathrm{~min}{ }^{-1}\right.$, $220 \mathrm{~nm}$ ). All peptides were characterized by MALDI-TOF MS using a Bruker Autoflex (Bruker, Billerica, MA, USA) with $\alpha$-cyano-4-hydroxycinnamic acid (CHCA) as the matrix. 


\subsection{Synthesis of Peptides with $\gamma$-Turn Inducers}

PCPA-Lys-4 peptides were synthesized using a modified strategy based on the published method for PCPA-Lys-4 H3-21 [22,25,28]. The synthesis of the protected mesyl-Lys-4 peptide sequence was accomplished on the resin based on standard Fmoc-based SPPS according to literature [44-46] and Boc-Ala-OH was used as the $\mathrm{N}$-terminal amino acid. The resin was treated with 5 equivalents of trans-2-phenylcyclopropylamine hydrochloride and 10 equivalents of $\mathrm{Et}_{3} \mathrm{~N}$ in 1:1 solution of $\mathrm{H}_{2} \mathrm{O} / \mathrm{CH}_{3} \mathrm{CN}$ for 3 days at room temperature. Deprotection and cleavage from the resin were performed with TFA/thioanisole $/ \mathrm{H}_{2} \mathrm{O}(85: 10: 5)$ solution. The desired peptide was collected by preparative RP-HPLC and lyophilized to give a white powder. MALDI-TOF MS $(\mathrm{m} / \mathrm{z})$ : Calcd. for PCPA-Lys-4 H3-11 (1) $\left([\mathrm{M}+\mathrm{H}]^{+}\right)$: 1364.529. Found: 1364.322. Calcd. for Aib peptide (2a) $\left([\mathrm{M}+\mathrm{H}]^{+}\right):$1305.572. Found: 1305.155. Calcd. for Acc peptide $(\mathbf{2 b})\left([\mathrm{M}+\mathrm{H}]^{+}\right):$1385.702. Found: 1385.293. Calcd. for Aadc peptide (2c) $\left([\mathrm{M}+\mathrm{H}]^{+}\right)$: 1489.854. Found: 1489.370.

\subsection{Assay for LSD1 Inhibitory Activity}

Assays for LSD1 inhibitory activity were performed using an LSD1 Fluorometric Drug Discovery Kit (Enzo Life Sciences, BML-AK544-0001). Inhibitors were pre-incubated with LSD1 (0.5 $\mu \mathrm{g} /$ well; room temperature; $15 \mathrm{~min}$ ) before reactions were initiated by the addition of H3K4me2 peptide $(2.3 \mu \mathrm{g} /$ well, $20 \mu \mathrm{M})$ into all wells except the blank. After incubation (room temperature; $30 \mathrm{~min}$ ), CeLLestial $^{\mathrm{TM}}$ Red and HRP in the assay buffer were added and the incubation was prolonged (room temperature; $5 \mathrm{~min}$ ). The fluorescence of the wells was measured on a $2030 \mathrm{ARVO}^{\mathrm{TM}} \mathrm{X} 3$ Multilabel Reader (PerkinElmer, Waltham, MA, USA, excitation: $540 \mathrm{~nm}$; detection: $590 \mathrm{~nm}$ ) and \% inhibition was calculated from the fluorescence readings of inhibited wells relative to those of control wells. The concentration of test compounds that resulted in $50 \%$ inhibition was determined by plotting $\log [\mathrm{Inh}]$ against the logit function of the $\%$ inhibition. $\mathrm{IC}_{50}$ values were determined by regression analysis of the concentration/inhibition data.

\subsection{Assay for MAO Inhibitory Activity}

Assays for MAO inhibitory activity were carried out according to the supplier's protocol using a MAO-Glo ${ }^{\text {TM }}$ Assay System (Promega, V1401). MAO-A (18 units $/ \mathrm{mL}$ ) or MAO-B (6 units $/ \mathrm{mL}$ ) (Sigma-Aldrich, Saint Louis, MO, USA, $25 \mu \mathrm{L} /$ well), $160 \mu \mathrm{M}$ (for MAO-A) or $16 \mu \mathrm{M}$ (for MAO-B) (4S)-4,5-dihydro-2-(6-hydroxybenzothiazolyl)-4-thiazolecarboxylic acid (12.5 $\mu \mathrm{L} /$ well), a MAO substrate, and various concentrations of inhibitors $(12.5 \mu \mathrm{L} /$ well $)$ were incubated at room temperature. Reactions were stopped after $60 \mathrm{~min}$ by adding reconstituted Luciferin Detection Reagent ( $50 \mu \mathrm{L} /$ well). Then, 20 min after the addition of this reagent, the chemiluminescence of the wells was measured with a $2030 \mathrm{ARVO}^{\mathrm{TM}}$ X3 Multilabel Reader (PerkinElmer). For data processing, the same procedure as that for LSD1 inhibitory activity was used.

\section{Conclusions}

In summary, we described the design, synthesis, and in vitro evaluation of the LSD1 inhibitory activities of novel histone H3 peptide-based LSD1 inactivators $2 a-c$ incorporating $\alpha, \alpha$-disubstituted amino acids as $\gamma$-turn inducers. We revealed that the peptides $\mathbf{2} \mathbf{a}-\mathbf{c}$ were potent and selective LSD1 inactivators compared to reference peptide $\mathbf{1}$. In particular, peptide $\mathbf{2 b}$ incorporating one Acc on each side of lysine residue bearing a PCPA moiety was the most potent and selective LSD1 inactivator. These findings are useful for the further development of histone H3 peptide-based LSD1 inactivators. Detailed studies of peptides incorporating $\gamma$-turn inducers are underway in our laboratory.

Supplementary Materials: Figure S1: Tine-dependent inhibition of LSD1 by $\mathbf{2 a} \mathbf{a} \mathbf{2} \mathbf{b}$ and $\mathbf{2 c}$, Figure S2: KDM4C inhibitory activities of $\mathbf{2} \mathbf{a}, \mathbf{2} \mathbf{b}$ and $\mathbf{2 b}$, Figure S3: View of the binding pose of a model peptide based on $\mathbf{2 b}$ in the active pocket of LSD1. 
Author Contributions: T.S. conceived and designed the experiments; T.S. and Y.I. supervised the experiments; T.K. synthesized the peptides; Y.O. performed the biological experiments; Y.O. and Y.I. performed the docking study; Y.O., T.K., Y.I. and T.S. discussed and wrote the manuscript.

Acknowledgments: We thank Takaki Koide for technical support. This work was supported in part by the Waseda University Grant for Special Research Projects (T.K.; project number 2015K-191, 2017B-151, 2017K-199), a Grant-in-Aid for Scientific Research (T.K.; C, 26460159) from MEXT (The Ministry of Education, Culture, Sports, Science and Technology), the JST CREST program (T.S.; JPMJCR14L2), and the Project for Cancer Research and Therapeutic Evolution (T.S.).

Conflicts of Interest: The authors declare no conflicts of interest.

\section{References}

1. Greer:, E.L.; Shi, Y. Histone methylation: A dynamic mark in health, disease and inheritance. Nat. Rev. Genet. 2012, 13, 343-357. [CrossRef] [PubMed]

2. Shi, Y.; Lan, F.; Matson, C.; Mulligan, P.; Whetstine, J.R.; Cole, P.A.; Casero, R.A.; Shi, Y. Histone Demethylation Mediated by the Nuclear Amine Oxidase Homolog LSD1. Cell 2004, 119, 941-953. [CrossRef] [PubMed]

3. Metzger, E.; Wissmann, M.; Yin, N.; Müller, J.M.; Schneider, R.; Peters, A.H.F.M.; Günther, T.; Buettner, R.; Schüle, R. LSD1 demethylates repressive histone marks to promote androgen-receptor-dependent transcription. Nature 2005, 437, 436-439. [CrossRef] [PubMed]

4. Huang, J.; Sengupta, R.; Espejo, A.B.; Lee, M.G.; Dorsey, J.A.; Richter, M.; Opravil, S.; Shiekhattar, R.; Bedford, M.T.; Jenuwein, T.; et al. p53 is regulated by the lysine demethylase LSD1. Nature 2007, 449, 105-108. [CrossRef] [PubMed]

5. Wang, J.; Hevi, S.; Kurash, J.K.; Lei, H.; Gay, F.; Bajko, J.; Su, H.; Sun, W.; Chang, H.; Xu, G.; et al. The lysine demethylase LSD1 (KDM1) is required for maintenance of global DNA methylation. Nat. Genet. 2009, 41, 125-129. [CrossRef] [PubMed]

6. Kontaki, H.; Talianidis, I. Lysine Methylation Regulates E2F1-Induced Cell Death. Mol. Cell 2010, 39, $152-160$. [CrossRef] [PubMed]

7. Lee, M.G.; Wynder, C.; Cooch, N.; Shiekhattar, R. An essential role for CoREST in nucleosomal histone 3 lysine 4 demethylation. Nature 2005, 437, 432-435. [CrossRef]

8. Saleque, S.; Kim, J.; Rooke, H.M.; Orkin, S.H. Epigenetic regulation of hematopoietic differentiation by Gfi-1 and Gfi-1b is mediated by the cofactors CoREST and LSD1. Mol. Cell 2007, 27, 562-572. [CrossRef] [PubMed]

9. Yokoyama, A.; Takezawa, S.; Schüle, R.; Kitagawa, H.; Kato, S. Transrepressive function of TLX requires the histone demethylase LSD1. Mol. Cell. Biol. 2008, 28, 3995-4003. [CrossRef] [PubMed]

10. Tsai, M.-C.; Manor, O.; Wan, Y.; Mosammaparast, N.; Wang, J.K.; Lan, F.; Shi, Y.; Segal, E.; Chang, H.Y. Long Noncoding RNA as Modular Scaffold of Histone Modification Complexes. Science 2010, 329, 689-693. [CrossRef] [PubMed]

11. Wissmann, M.; Yin, N.; Müller, J.M.; Greschik, H.; Fodor, B.D.; Jenuwein, T.; Vogler, C.; Schneider, R.; Günther, T.; Buettner, R.; et al. Cooperative demethylation by JMJD2C and LSD1 promotes androgen receptor-dependent gene expression. Nat. Cell Biol. 2007, 9, 347-353. [CrossRef] [PubMed]

12. Højfeldt, J.W.; Agger, K.; Helin, K. Histone lysine demethylases as targets for anticancer therapy. Nat. Rev. Drug Discov. 2013, 12, 917-930. [CrossRef] [PubMed]

13. Shi, L.; Cui, S.; Engel, J.D.; Tanabe, O. Lysine-specific demethylase 1 is a therapeutic target for fetal hemoglobin induction. Nat. Med. 2013, 19, 291-294. [CrossRef] [PubMed]

14. Liang, Y.; Vogel, J.L.; Narayanan, A.; Peng, H.; Kristie, T.M. Inhibition of the histone demethylase LSD1 blocks $\alpha$-herpesvirus lytic replication and reactivation from latency. Nat. Med. 2009, 15, 1312-1317. [CrossRef] [PubMed]

15. Suzuki, T.; Miyata, N. Lysine Demethylases Inhibitors. J. Med. Chem. 2011, 54, 8236-8250. [CrossRef] [PubMed]

16. Wang, X.; Huang, B.; Suzuki, T.; Liu, X.; Zhan, P. Medicinal chemistry insights in the discovery of novel LSD1 inhibitors. Epigenomics 2015, 7, 1379-1396. [CrossRef] [PubMed]

17. McAllister, T.E.; England, K.S.; Hopkinson, R.J.; Brennan, P.E.; Kawamura, A.; Schofield, C.J. Recent Progress in Histone Demethylase Inhibitors. J. Med. Chem. 2016, 59, 1308-1329. [CrossRef] [PubMed] 
18. Maes, T.; Mascaró, C.; Ortega, A.; Lunardi, S.; Ciceri, F.; Somervaille, T.C.P.; Buesa, C. KDM1 histone lysine demethylases as targets for treatments of oncological and neurodegenerative disease. Epigenomics 2015, 7, 609-626. [CrossRef] [PubMed]

19. Mohammad, H.P.; Smitheman, K.N.; Kamat, C.D.; Soong, D.; Federowicz, K.E.; Van Aller, G.S.; Schneck, J.L.; Carson, J.D.; Liu, Y.; Butticello, M.; et al. A DNA Hypomethylation Signature Predicts Antitumor Activity of LSD1 Inhibitors in SCLC. Cancer Cell 2015, 28, 57-69. [CrossRef] [PubMed]

20. Ueda, R.; Suzuki, T.; Mino, K.; Tsumoto, H.; Nakagawa, H.; Hasegawa, M.; Sasaki, R.; Mizukami, T.; Miyata, N. Identification of Cell-Active Lysine Specific Demethylase 1-Selective Inhibitors. J. Am. Chem. Soc. 2009, 131, 17536-17537. [CrossRef] [PubMed]

21. Ogasawara, D.; Suzuki, T.; Mino, K.; Ueda, R.; Khan, M.N.A.; Matsubara, T.; Koseki, K.; Hasegawa, M.; Sasaki, R.; Nakagawa, H.; et al. Synthesis and biological activity of optically active NCL-1, a lysine-specific demethylase 1 selective inhibitor. Bioorg. Med. Chem. 2011, 19, 3702-3708. [CrossRef] [PubMed]

22. Ogasawara, D.; Itoh, Y.; Tsumoto, H.; Kakizawa, T.; Mino, K.; Fukuhara, K.; Nakagawa, H.; Hasegawa, M.; Sasaki, R.; Mizukami, T.; et al. Lysine-Specific Demethylase 1-Selective Inactivators: Protein-Targeted Drug Delivery Mechanism. Angew. Chem. Int. Ed. 2013, 52, 8620-8624. [CrossRef] [PubMed]

23. Itoh, Y.; Ogasawara, D.; Ota, Y.; Mizukami, T.; Suzuki, T. Synthesis, LSD1 Inhibitory Activity, and LSD1 Binding Model of Optically Pure Lysine-PCPA Conjugates. Comput. Struct. Biotechnol. J. 2014, 9, e201402002. [CrossRef] [PubMed]

24. Ahmed Khan, M.N.; Tsumoto, H.; Itoh, Y.; Ota, Y.; Suzuki, M.; Ogasawara, D.; Nakagawa, H.; Mizukami, T.; Miyata, N.; Suzuki, T. Design, synthesis, and biological activity of N-alkylated analogue of NCL1, a selective inhibitor of lysine-specific demethylase 1. Medchemcomm 2015, 6, 407-412. [CrossRef]

25. Kakizawa, T.; Ota, Y.; Itoh, Y.; Tsumoto, H.; Suzuki, T. Histone H3 peptide based LSD1-selective inhibitors. Bioorg. Med. Chem. Lett. 2015, 25, 1925-1928. [CrossRef] [PubMed]

26. Itoh, Y.; Aihara, K.; Mellini, P.; Tojo, T.; Ota, Y.; Tsumoto, H.; Solomon, V.R.; Zhan, P.; Suzuki, M.; Ogasawara, D.; et al. Identification of SNAIL1 Peptide-Based Irreversible Lysine-Specific Demethylase 1-Selective Inactivators. J. Med. Chem. 2016, 59, 1531-1544. [CrossRef] [PubMed]

27. Miyamura, S.; Araki, M.; Ota, Y.; Itoh, Y.; Yasuda, S.; Masuda, M.; Taniguchi, T.; Sowa, Y.; Sakai, T.; Suzuki, T.; et al. C-H activation enables a rapid structure-activity relationship study of arylcyclopropyl amines for potent and selective LSD1 inhibitors. Org. Biomol. Chem. 2016, 14, 8576-8585. [CrossRef] [PubMed]

28. Kakizawa, T.; Ota, Y.; Itoh, Y.; Suzuki, T. Histone H3 peptides incorporating modified lysine residues as lysine-specific demethylase 1 inhibitors. Bioorg. Med. Chem. Lett. 2018, 28, 167-169. [CrossRef] [PubMed]

29. Ota, Y.; Miyamura, S.; Araki, M.; Itoh, Y.; Yasuda, S.; Masuda, M.; Taniguchi, T.; Sowa, Y.; Sakai, T.; Itami, K.; et al. Design, synthesis and evaluation of $\gamma$-turn mimetics as LSD1-selective inhibitors. Bioorg. Med. Chem. 2018, 26, 775-785. [CrossRef] [PubMed]

30. Schmidt, D.M.Z.; McCafferty, D.G. trans-2-Phenylcyclopropylamine is a mechanism-based inactivator of the histone demethylase LSD1. Biochemistry 2007, 46, 4408-4416. [CrossRef] [PubMed]

31. Yang, M.; Culhane, J.C.; Szewczuk, L.M.; Jalili, P.; Ball, H.L.; Machius, M.; Cole, P.A.; Yu, H. Structural Basis for the Inhibition of the LSD1 Histone Demethylase by the Antidepressant trans-2-Phenylcyclopropylamine. Biochemistry 2007, 46, 8058-8065. [CrossRef] [PubMed]

32. Sareddy, G.R.; Viswanadhapalli, S.; Surapaneni, P.; Suzuki, T.; Brenner, A.; Vadlamudi, R.K. Novel KDM1A inhibitors induce differentiation and apoptosis of glioma stem cells via unfolded protein response pathway. Oncogene 2017, 36, 2423-2434. [CrossRef] [PubMed]

33. Sugino, N.; Kawahara, M.; Tatsumi, G.; Kanai, A.; Matsui, H.; Yamamoto, R.; Nagai, Y.; Fujii, S.; Shimazu, Y.; Hishizawa, M.; et al. A novel LSD1 inhibitor NCD38 ameliorates MDS-related leukemia with complex karyotype by attenuating leukemia programs via activating super-enhancers. Leukemia 2017, 31, 2302-2314. [CrossRef] [PubMed]

34. Yang, M.; Culhane, J.C.; Szewczuk, L.M.; Gocke, C.B.; Brautigam, C.A; Tomchick, D.R.; Machius, M.; Cole, P.A.; Yu, H. Structural basis of histone demethylation by LSD1 revealed by suicide inactivation. Nat. Struct. Mol. Biol. 2007, 14, 535-539. [CrossRef] [PubMed]

35. Kuroda, Y.; Ueda, H.; Nozawa, H.; Ogoshi, H. Adamantyl amino acid as $\gamma$-turn inducer for peptide. Tetrahedron Lett. 1997, 38, 7901-7904. [CrossRef] 
36. Youdim, M.B.H.; Edmondson, D.; Tipton, K.F. The therapeutic potential of monoamine oxidase inhibitors. Nat. Rev. Neurosci. 2006, 7, 295-309. [CrossRef] [PubMed]

37. Whetstine, J.R.; Nottke, A.; Lan, F.; Huarte, M.; Smolikov, S.; Chen, Z.; Spooner, E.; Li, E.; Zhang, G.; Colaiacovo, M.; et al. Reversal of Histone Lysine Trimethylation by the JMJD2 Family of Histone Demethylases. Cell 2006, 125, 467-481. [CrossRef] [PubMed]

38. Christophersen, P.C.; Fano, M.; Saaby, L.; Yang, M.; Nielsen, H.M.; Mu, H. Characterization of particulate drug delivery systems for oral delivery of Peptide and protein drugs. Curr. Pharm. Des. 2015, 21, 2611-2628. [CrossRef] [PubMed]

39. Kumarasinghe, I.R.; Woster, P.M. Synthesis and Evaluation of Novel Cyclic Peptide Inhibitors of Lysine-Specific Demethylase 1. ACS Med. Chem. Lett. 2014, 5, 29-33. [CrossRef] [PubMed]

40. Kumarasinghe, I.R.; Woster, P.M. Cyclic by peptide inhibitors of lysine-specific demethylase 1 with improved potency identified by alanine scanning mutagenesis. Eur. J. Med. Chem. 2018, 148, 210-220. [CrossRef] [PubMed]

41. Meng, X.; Li, J.; Zheng, M.; Zuo, L.; Sun, C.; Zhu, Y.; Fang, L.; Liu, L.; Zhou, X. Stable H3 peptide was delivered by gold nanorods to inhibit LSD1 activation and induce human mesenchymal stem cells differentiation. Oncotarget 2017, 8, 23110-23119. [CrossRef] [PubMed]

42. Karstad, R.; Isaksen, G.; Brandsdal, B.O.; Svendsen, J.S.; Svenson, J. Unnatural amino acid side chains as S1, $\mathrm{S}^{\prime}$, and S2' probes yield cationic antimicrobial peptides with stability toward chymotryptic degradation. J. Med. Chem. 2010, 53, 5558-5566. [CrossRef] [PubMed]

43. Brimble, M.A.; Kowalczyk, R.; Harris, P.W.R.; Dunbar, P.R.; Muir, V.J. Synthesis of fluorescein-labelled $O$-mannosylated peptides as components for synthetic vaccines: Comparison of two synthetic strategies. Org. Biomol. Chem. 2008, 6, 112-121. [CrossRef] [PubMed]

44. Culhane, J.C.; Wang, D.; Yen, P.M.; Cole, P.A. Comparative analysis of small molecules and histone substrate analogues as LSD1 lysine demethylase inhibitors. J. Am. Chem. Soc. 2010, 132, 3164-3176. [CrossRef] [PubMed]

45. Szewczuk, L.M.; Culhane, J.C.; Yang, M.; Majumdar, A.; Yu, H.; Cole, P.A. Mechanistic analysis of a suicide inactivator of histone demethylase LSD1. Biochemistry 2007, 46, 6892-6902. [CrossRef] [PubMed]

46. Culhane, J.C.; Szewczuk, L.M.; Liu, X.; Da, G.; Marmorstein, R.; Cole, P.A. A mechanism-based inactivator for histone demethylase LSD1. J. Am. Chem. Soc. 2006, 128, 4536-4537. [CrossRef] [PubMed]

Sample Availability: Not available.

(C) 2018 by the authors. Licensee MDPI, Basel, Switzerland. This article is an open access article distributed under the terms and conditions of the Creative Commons Attribution (CC BY) license (http:/ / creativecommons.org/licenses/by/4.0/). 